\title{
Sistem Pendukung Keputusan Pemilihan Supplier Dengan Menggunakan SMART Pada CV. Hamuas Mandiri
}

\author{
Maya Nur Amalia' ${ }^{1)}$ Maxsi Ary ${ }^{2)}$ \\ 1)2) Jurusan Sistem Informasi, Fakultas Teknologi Informasi, ARS University \\ Jl. Terusan Sekolah No.1-2, Cicaheum, Kec. Kiaracondong, Kota Bandung, Jawa Barat 40282 \\ ${ }^{1)}$ mayanuramalia209@gmail.com \\ ${ }^{2)}$ maxsi@ars.ac.id
}

\begin{abstract}
Abstrak
CV. Hamuas Mandiri merupakan salah satu perusahaan industri yang bergerak di bidang produksi kerajinan yang menjadikan bambu sebagai bahan utamanya, dimana dalam pemilihan supplier pada CV. Hamuas Mandiri masih dijalankan berdasarkan hubungan relasi saja tetapi tidak disertai dengan metode dan kriteria yang tepat, tentu hal tersebut kurang efektif untuk dilakukan. Tujuan dari penelitian adalah membuat sistem pendukung keputusan untuk pemilihan supplier bambu. SPK penentuan supplier bambu diharapkan dapat menjadi alternatif penyelesaian persoalan penentuan supplier pada CV. Hamuas Mandiri. Metode penentuan supplier yang digunakan dalam penelitian ini menggunakan metode Simple Multi Attribute Rating Technique (SMART) yang merupakan suatu teknik pengambilan keputusan yang multi kriteria. Hasil dari penelitian ini adalah adanya suatu sistem pendukung keputusan untuk dapat membantu dan memberikan kemudahan bagi perusahaan dalam menentukan supplier terbaik dengan standar kriteria yang sesuai dengan perusahaan inginkan.
\end{abstract}

Kata kunci: Pemilihan Supplier, SMART, Sistem Pendukung Keputusan

\begin{abstract}
$C V$. Hamuas Mandiri is one of the industrial companies engaged in the production of handicrafts that make bamboo as the main material, where in the selection of suppliers on CV. Hamuas Mandiri is still run based on relationships but is not accompanied by the right methods and criteria, of course this is less effective to do. The purpose of this research is to make a decision support system for the selection of bamboo suppliers. SPK for determining bamboo suppliers is expected to be an alternative solution to the problem of determining suppliers in CV. Hamuas Mandiri. The supplier determination method used in this study uses the Simple Multi Attribute Rating Technique (SMART) method, which is a multi-criteria decision-making technique. The results of this study are the existence of a decision support system to be able to assist and provide convenience for companies in determining the best suppliers with standard criteria that are in accordance with the company's wishes.
\end{abstract}

Keywords: Supplier Selection, SMART, Decision Support System

\section{PENDAHULUAN}

Persaingan industri membuat perusahaan menyadari betapa pentingnya pemilihan supplier yang tepat dalam memenuhi kebutuhan perusahaan dalam kegiatan bisnisnya agar pemilihan supplier tersebut sesuai dengan kriteria yang diinginkan [1]. Supplier merupakan hal yang tidak dapat dipisahkan dari kegiatan bisnis, dikarenakan supplier memiliki peranan yang sangat penting dalam operasional bisnis agar bisnis tersebut dapat berjalan dengan lancar. Pemilihan supplier yang kompeten dalam pembelian bahan baku menjadikan langkah awal bagi perusahaan dalam pemilihan bahan baku yang berkualitas untuk tetap menjaga kualitas produk pada perusahaan [2]. 
Jika sebuah perusahaan melakukan kesalahan dalam pemilihan supplier akan sangat mempengaruhi kinerja dari suatu perusahaan tersebut. Kesalahan dalam pemilihan supplier khususnya supplier bahan baku akan sangat berakibat fatal pada penurunan produktivitas perusahaan [3]. Hal ini dikarenakan bahan baku merupakan hal terpenting dalam suatu kegiatan proses produksi, yang dimana jika supplier bahan baku yang dipilih kurang kompeten terhadap permintaan atau supplier yang dipilih melakukan kesalahan baik keterlambatan dalam waktu pengiriman, kuantitas, ataupun barang yang dikirim tidak sesuai dengan permintaan perusahaan tentu akan sangat berdampak secara langsung terhadap kinerja perusahaan tersebut. Untuk dapat mempermudah perusahaan dalam pemilihan supplier, maka dibutuhkan sebuah sistem pendukung keputusan yang dimana diharapkan dapat menyelesaikan masalah-masalah yang ada pada perusahaan [4].

Sama hal pula yang dibutuhkan oleh CV. Hamuas Mandiri. Sebuah perusahaan industri yang bergerak dibidang produksi kerajinan yang menjadikan bambu sebagai bahan utamanya juga membutuhkan sebuah sistem pendukung keputusan yang dapat membantu semaksimal mungkin dalam pemilihan supplier yang lebih efektif dan efesien sehingga dapat mempermudah perusahaan dalam pengambilan sebuah keputusan pemilihan supplier terbaik dengan standar kriteria yang sesuai dengan perusahaan inginkan. Sebelumnya dalam pemilihan supplier pada CV. Hamuas Mandiri masih dijalankan berdasarkan intuisi atau hubungan relasai saja tetapi tidak disertai dengan metode dan kriteria yang tepat, tentu hal tersebut kurang efektif untuk dilakukan. Dimana dengan pemilihan supplier yang dilakukan seperti itu akan mengakibatkan munculnya berbagai macam permasalahan, seperti ketidaksesuaian jumlah produk, kualitas produk yang tidak sesuai yang diinginkan, serta terjadinya keterlambatan dalam pengiriman. Hal tersebut pernah dialami oleh CV. Hamuas Mandiri, dimana CV. Hamuas Mandiri pernah dihadapkan dalam sebuah kendala yaitu terlambatnya supplier dalam pengiriman bahan baku yang menyebabkan terganggunya dalam kegiatan operasional perusahaan yang mengakibatkan terlambatnya pengiriman barang ke konsumen. Jika hal tersebut terus berlanjut tentu dapat menimbulkan kerugian bagi perusahaan baik dari segi waktu, biaya, tenaga, serta hilangnya kepercayaan konsumen terhadap perusahaan.

Sehingga dari permasalahan yang terjadi diatas, maka perusahaan membutuhkan suatu sistem pendukung keputusan dalam menentukan supplier terbaik. Metode yang akan digunakan dalam memecahkan permasalahan ini yaitu menggunakan metode Simple Multi Attribute Rating Technique (SMART) untuk membantu dalam memproses menentukan supplier dengan standar kriteria-kriteria yang ditetapkan perusahaan untuk menghasilkan keputusan yang lebih akurat dan cepat [5]. Berdasarkan permasalahan yang terjadi diatas maka penulis mengambil judul "Sistem Pendukung Keputusan Pemilihan Supplier Dengan Menggunakan Metode Simple Multi Attribute Rating Technique (SMART) Pada CV. Hamuas Mandiri”.

\section{TINJAUAN PUSTAKA}

\subsection{Sistem Pendukung Keputusan (Decision Support System)}

Sistem adalah suatu kumpulan entitas atau komponen yang saling berhubungan satu sama lain untuk mencapai tujuan tertentu [6]. Sistem Pendukung Keputusan (Decision Support System) adalah suatu sistem yang difokuskan untuk membantu dalam meyelesaikan suatu masalah dengan menghasilkan berbagai macam alternatif keputusan untuk membantu manajemen dalam mengatasi permasalahan pengambilan keputusan pada suatu perusahaan atau organisasi dengan menggunakan data dan model [7].

\subsection{Pemasok (Supplier)}

Pemasok (Supplier) adalah perusahaan atau individu yang memasok kebutuhan bahan baku perusahaan atau individu lain untuk dijadikan sebagai jasa atau barang [8]. 


\subsection{Metode Simple Multi Attribute Rating Technique (SMART)}

Metode SMART diperkenalkan oleh Edward tahun 1997 dan merupakan teknik pengambilan keputusan yang multi kriteria yang berlandaskan pada suatu teori yang menyatakan bahwa tiaptiap alternatif terdiri dari beberapa kriteria yang mempunyai nilai-nilai serta masing-masing dari kriteria tersebut mempunyai bobot yang mendeskripsikan seberapa penting kriteria tersebut dengan kriteria lainnya. Kesederhanaan metode SMART dalam menganalisa respon, menanggapi keinginan pembuat keputusan, serta kesederhanaan perhitungan dalam pengambilan keputusan dengan menggunakan metode SMART yang dinilai cukup ampuh dalam menyelesaikan masalah membuat metode ini lebih kerap digunakan [7]. Berikut tahapan-tahapan dalam metode SMART sebagai berikut:

1. Menetapkan kriteria apa yang akan dipakai dalam mengatasi permasalahan dalam pengambilan keputusan tersebut.

2. Menentukan bobot kriteria, dimana pada tahapan ini memberikan bobot kriteria tersebut dengan memakai interval penilaian 1-100 pada tiap-tiap kriteria dengan prioritas utama.

3. Normalisasi bobot kriteria, melakukan perhitungan normalisasi bobot tiap kriteria tersebut dengan melakukan perbandingkan nilai bobot kriteria tersebut dengan total kriteria.

4. Memberikan nilai parameter untuk tiap kriteria dengan memberikan nilai pada tiap kriteria alternatif tersebut baik dalam bentuk data kuantitatif (angka) maupun data kualitatif (sangat baik, baik, cukup baik, kurang baik).

5. Menentukan nilai utility dengan melakukan konversi nilai pada tiap-tiap kriteria menjadi suatu nilai kriteria data baku bergantung pada karakter kriteria sendiri.

6. Menentukan nilai akhir dari tiap-tiap kriteria dengan mengalikan nilai normalisasi bobot kriteria dengan nilai utility.

7. Perangkingan, dimana pada tahapan ini hasil dari nilai akhir akan diurutkan dari nilai yang terbesar sampai ke terkecil yang nantinya menujukkan alternatif mana yang terbaik dilihat dari nilai akhir alternatif tersebut.

\section{METODOLOGI PENELITIAN}

\subsection{Implementasi Metode SMART dalam Pemilihan Supplier Terbaik}

Metode SMART merupakan teknik pengambilan keputusan yang multi kriteria serta kesederhanaan metode dalam melakukan perhitungan pengambilan keputusan yang dinilai cukup ampuh dalam menyelesaikan masalah yang membuat metode ini lebih kerap digunakan. Berikut merupakan tahapan-tahapan dalam metode SMART sebagai berikut:

\section{Menentukan Kriteria}

Menetapkan kriteria apa yang akan dipakai dalam mengatasi permasalahan dalam pengambilan keputusan sebagai berikut:
A. Harga
B. Kualitas
C. Waktu Pengiriman
D. Pelayanan yang diberikan

\section{Menentukan Bobot Kriteria}

Dimana pada tahapan ini memberikan bobot kriteria tersebut dengan memakai interval penilaian 1-100 pada tiap-tiap kriteria dengan prioritas utama.

Tabel 1. Bobot kriteria

\begin{tabular}{clc}
\hline No. & \multicolumn{1}{c}{ Kriteria } & Bobot / Weight $(\mathbf{W})$ \\
\hline 1. & Harga & 100 \\
2. & Kualitas & 90 \\
3. & Waktu Pengiriman & 80 \\
4. & Pelayanan yang Diberikan & 80 \\
& Total & $\mathbf{3 5 0}$ \\
\hline
\end{tabular}


Dimana penentuan bobot yang ada ditabel diatas didapatkan dari hasil wawancara dengan narasumber menengenai seberapa pentingnya kriteria-kriteria tersebut dalam menentukan supplier dengan cara narasumber memberikan penilaian untuk setiap kriteria dengan menggunakan interval penilaian 1-100 yang dimana semakin besar nilai yang diberikan maka semakin berpengaruhnya kriteria tersebut dalam menentukan supplier.

\section{Normalisasi Bobot Kriteria}

Melakukan perhitungan normalisasi bobot tiap kriteria tersebut dengan melakukan perbandingkan nilai bobot kriteria tersebut dengan total kriteria.

Tabel 2. Normalisasi bobot kriteria

\begin{tabular}{cll}
\hline No. & Kriteria & \multicolumn{1}{c}{ Bobot / Weight $(\mathbf{W})$} \\
\hline 1. & Harga & $100 / 350=0.28571428571429$ \\
2. & Kualitas & $90 / 350=0.25714285714286$ \\
3. & Waktu Pengiriman & $80 / 350=0.22857142857143$ \\
4. & Pelayanan yang Diberikan & $80 / 350=0.22857142857143$ \\
\hline
\end{tabular}

\section{Memberikan Nilai Parameter untuk Setiap Kriteria}

Memberikan nilai pada tiap alternatif dengan kriteria yang sudah ditentukan baik dalam bentuk data kuantitatif (angka) maupun data kualitatif (sangat baik, baik, cukup baik, kurang baik). Dimana range nilai 1-60 (Kurang Baik), 61-70 (Cukup), 71-89 (Baik), 90-100 (Sangat Baik).

Tabel 3. Penilaian alternatif

\begin{tabular}{clcccc}
\hline No. & \multicolumn{1}{c}{ Alternatif } & Harga & Kualitas & $\begin{array}{c}\text { Waktu } \\
\text { Pengiriman }\end{array}$ & $\begin{array}{c}\text { Pelayanan yang } \\
\text { Diberikan }\end{array}$ \\
\cline { 3 - 5 } & & 75 & 80 & 80 & 70 \\
1. & CV. Ultra Mega & 80 & 100 & 75 & 75 \\
2. & PT. Jamafec & 70 & 75 & 80 & 70 \\
3. & CV. Mega Kayu Industri & 90 & 100 & 80 & 80 \\
4. & CV. Jaya Sakti & & & & \\
\hline
\end{tabular}

\section{Menentukan Nilai Utility}

Menentukan nilai utility dengan melakukan konversi nilai pada tiap-tiap kriteria menjadi suatu nilai kriteria data baku bergantung pada karakter kriteria itu sendiri.

A. Jika kriteria cost (lebih kecil = lebih baik):

$u_{i}\left(a_{i}\right)=100 \frac{\left(C_{\max }-C_{\min }\right)}{\left(C_{\max }-C_{\min }\right)} \%$

B. Jika kriteria benefit (lebih besar = lebih baik):

$u_{i}\left(a_{i}\right)=100 \frac{\left(C_{\text {out } i}-C_{\min }\right)}{\left(C_{\max }-C_{\min }\right)} \%$

Keterangan:

$u_{i}\left(a_{i}\right)=$ Nilai utility kriteria ke-i

$C_{\max }=$ Nilai kriteria maksimal

$C_{\min }=$ Nilai kriteria minimal

$C_{\text {out } i}=$ Nilai kriteria ke-i 
Tabel 4. Menentukan Nilai Utility

\begin{tabular}{clcccc}
\hline No. & \multicolumn{1}{c}{ Alternatif } & Harga & Kualitas & $\begin{array}{c}\text { Writeria } \\
\text { Pengiriman }\end{array}$ & $\begin{array}{c}\text { Pelayanan yang } \\
\text { Diberikan }\end{array}$ \\
\cline { 3 - 6 } & & 75 & 20 & 0 & 0 \\
1. & CV. Ultra Mega & 50 & 100 & 100 & 50 \\
2. & PT. Jamafec & 100 & 0 & 0 & 0 \\
3. & CV. Mega Kayu Industri & 0 & 100 & 0 & 100 \\
4. & CV. Jaya Sakti & & & & \\
\hline
\end{tabular}

\section{Menentukan Nilai Akhir}

Menentukan nilai akhir dari tiap-tiap kriteria dengan mengalikan nilai normalisasi bobot kriteria dengan nilai utility.

$\mathrm{u}\left(a_{i}\right)=\sum_{j=1}^{m} w_{j} u_{i}\left(a_{i}\right), i=1,2, \ldots m$

Keterangan:

$\mathrm{u}\left(a_{i}\right)=$ Nilai utility kriteria ke-i

$w_{j}=$ Nilai bobot kriteria ke-j yang sudah ternormalisasi

$u_{i}\left(a_{i}\right)=$ Nilai utility kriteria ke-j untuk alternatif ke-i

Tabel 5. Menentukan nilai akhir

\begin{tabular}{cccccc}
\hline & & \multicolumn{3}{c}{ Kriteria } \\
\cline { 3 - 5 } No. & Alternatif & Harga & Kualitas & $\begin{array}{c}\text { Waktu } \\
\text { Pengiriman }\end{array}$ & $\begin{array}{c}\text { Pelayanan yang } \\
\text { Diberikan }\end{array}$ \\
\hline 1. & CV. Ultra Mega & 21.429 & 5.143 & 0 & 0 \\
2. & PT. Jamafec & 14.286 & 25.714 & 22.857 & 11.429 \\
3. & CV. Mega Kayu Industri & 28.571 & 0 & 0 & 0 \\
4. & CV. Jaya Sakti & 0 & 25.714 & 0 & 22.857 \\
\hline
\end{tabular}

\section{Perangkingan}

Dimana pada tahapan ini hasil dari nilai akhir akan diurutkan dari nilai yang terbesar sampai ke terkecil yang nantinya menujukkan alternatif mana yang terbaik dilihat dari nilai akhir alternatif tersebut.

Tabel 6. Perangkingan alternatif

\begin{tabular}{clcc}
\hline No. & \multicolumn{1}{c}{ Alternatif } & Nilai Akhir & Rangking \\
\hline 1. & CV. Ultra Mega & 26.572 & 4 \\
2. & PT. Jamafec & 74.386 & 1 \\
3. & CV. Mega Kayu Industri & 28.571 & 3 \\
4. & CV. Jaya Sakti & 48.571 & 2 \\
\hline
\end{tabular}

\section{PEMBAHASAN}

Berikut ini merupakan rancangan sistem pendukung keputusan pemilihan supplier dengan menggunakan metode SMART pada CV. Hamuas Mandiri.

\subsection{Use case diagram}

Pada Gambar dibawah merupakan use case diagram dalam menggunakan aplikasi pemilihan supplier. Terdapat interaksi yang dilakukan antara actor yaitu administartor dengan aplikasi dalam mengakses login, mengelola data kriteria (menambah, mengubah, serta menghapus data kriteria), mengelola data alternatif (menambah, mengubah, serta menghapus data alternatif), melihat penilaian, melihat laporan Penilaian, mengubah password, hingga mengelola data admin. 


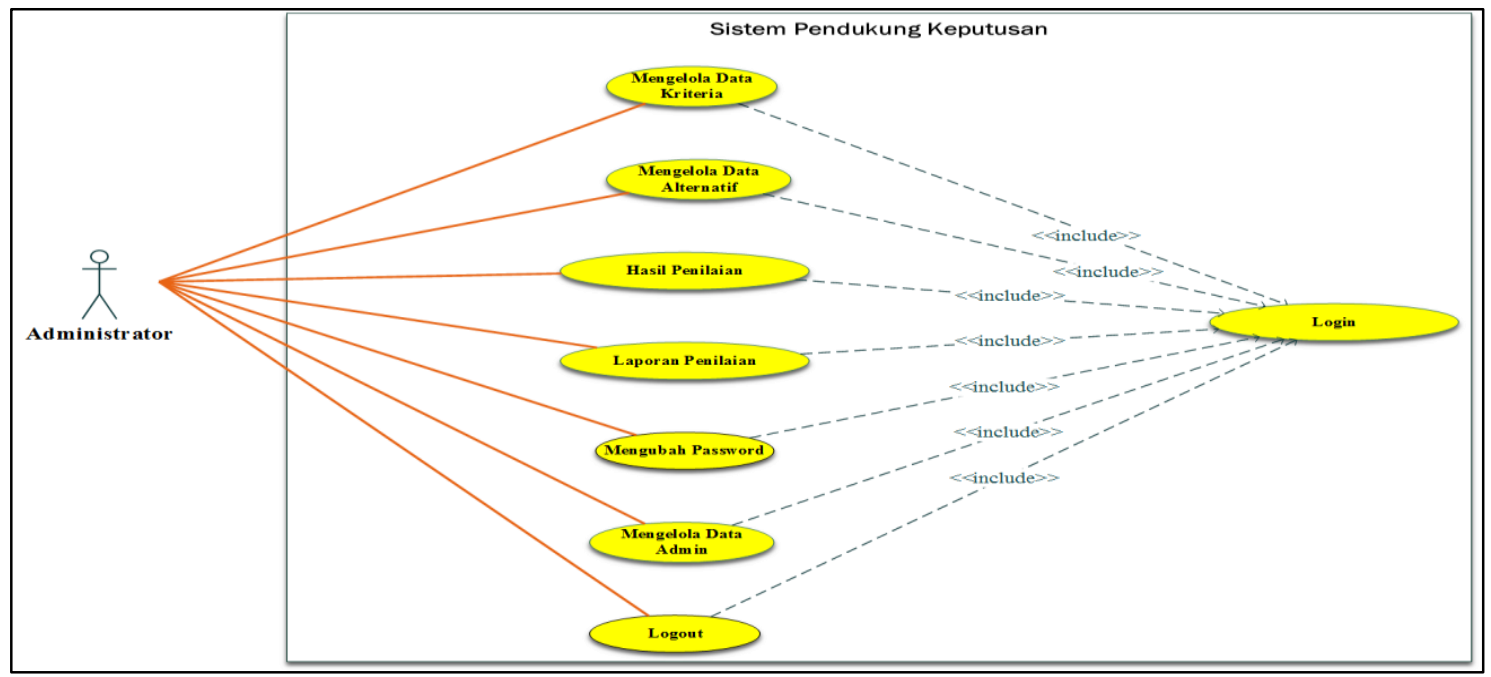

Gambar 1. Use case diagram sistem pendukung keputusan

\subsection{User Interface}

Pada tahapan ini akan menampilkan tampilan-tampilan program dari sistem pendukung keputusan pemilihan supplier di CV. Hamuas Mandiri.

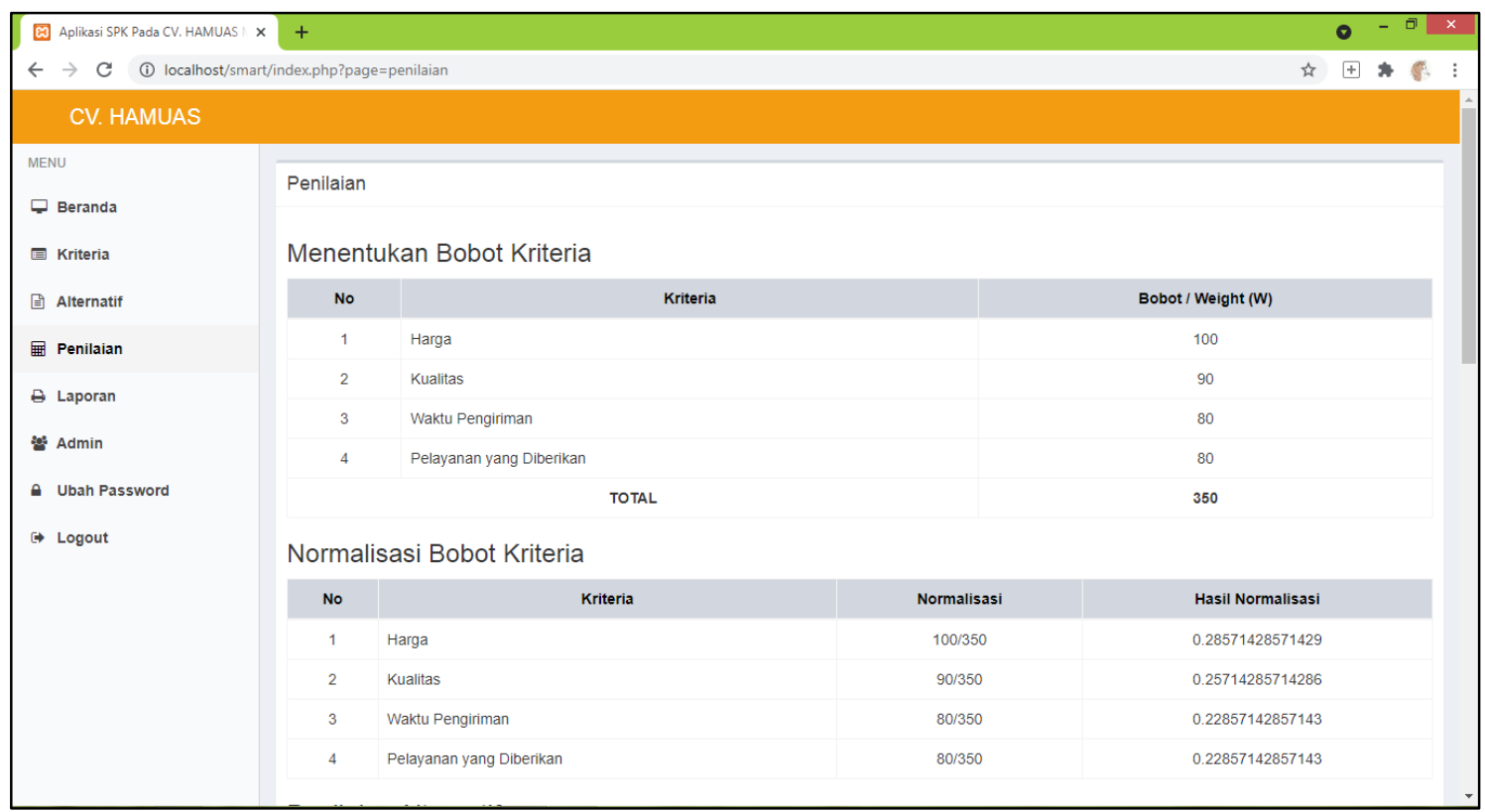

Gambar 2. Tampilan halaman Penilaian

Pada halaman penilaian ini menampilkan hasil data penilaian yang sudah dilakukan pengujian dengan menggunakan metode SMART yang dimana hasil data penilaian ini akan menentukan hasil laporan dalam menentukkan supplier yang tepat yang sesuai dengan standar perusahaan inginkan. 


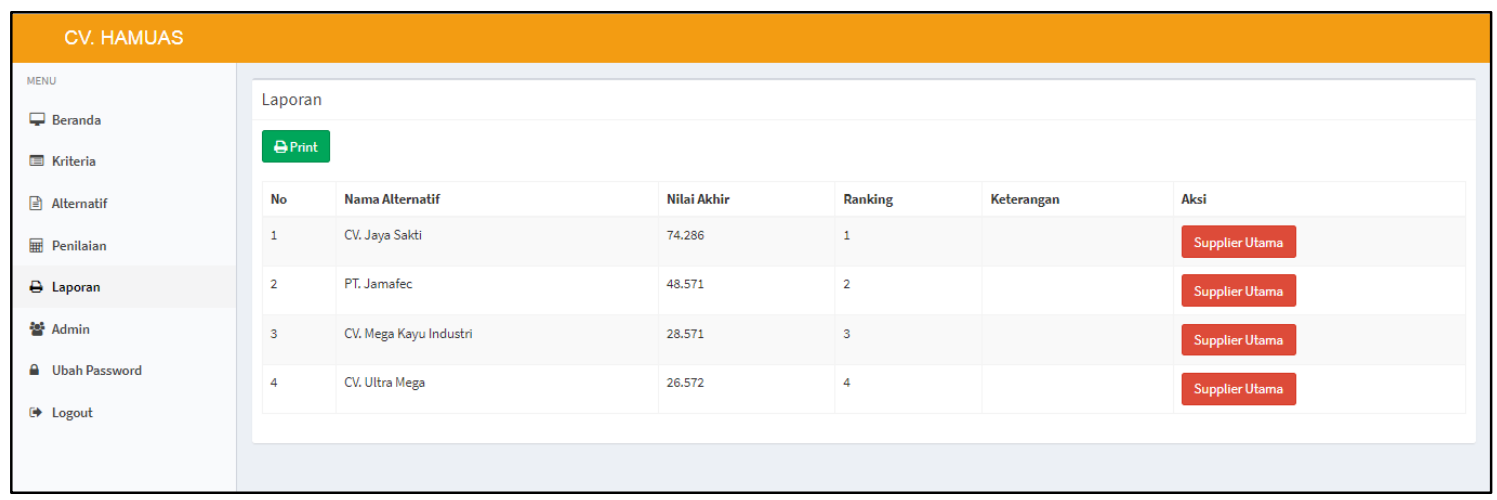

Gambar 3. Tampilan Halaman Laporan

Pada halaman laporan diatas menampilkan urutan rangking supplier yang telah dilakukan pengolahan data dengan menggunakan metode SMART yang dimana pada halaman ini memberikan sebuah rekomendasi dalam menentukkan supplier yang sesuai dengan perusahaan inginkan berdasarkan urutan rangking yang ada dilaporan. Dimana semakin besar nilai akhir atau semakin tinggi rangking tersebut maka menunjukkan bahwa supplier tersebut terbaik untuk dilakukan kerja sama dalam memasok bahan baku utama perusahaan.

\section{KESIMPULAN}

Berdasarkan pembahasan yang sudah dipaparkan dalam penulisan skripsi Sistem Pendukung Keputusan Pemilihan Supplier Dengan Menggunakan Metode Simple Multi Attribute Rating Technique (SMART) Pada CV. Hamuas Mandiri, maka didapatkan beberapa kesimpulan yaitu.

1. Dengan adanya sistem pendukung keputusan menggunakan metode Simple Multi Attribute Rating Technique (SMART) di CV. Hamuas Mandiri membantu dan mempermudah perusahaan dalam pengambilan keputusan untuk menentukan supplier terbaik dengan menghasilkan informasi secara tepat dan cepat. Hal ini dikarenakan dengan adanya sistem pendukung keputusan ini perusahaan mendapatkan rekomendasi supplier yang tepat yang sesuai dengan standar kriteria perusahaan inginkan.

2. Dari aplikasi sistem pendukung keputusan yang telah dibangun berbasis website ini menggunakan metode SMART dengan kriteria yang terdiri dari harga, kualitas, waktu pengiriman, serta pelayanan yang diberikan, didapatkan urutan perangkingan hasil yang dimana PT. Jamafec memperoleh hasil akhir 74,286, CV. Jaya Sakti 48,571, CV. Mega Kayu Industri 28,571, dan CV. Ultra Mega 26,572 yang dimana hasil perangkingan tersebut dapat dijadikan sebagai rekomendasi untuk perusahaan dalam menentukan supplier terbaik dengan standar kriteria yang perusahaan inginkan.

\section{DAFTAR PUSTAKA}

[1] F. M. U. Hasiani, T. Haryanti, R. Rinawati, and L. Kurniawati, "Sistem Pendukung Keputusan Pemilihan Supplier Produk Ritel dengan Metode Analytical Hierarchy Process," Sist. J. Sist. Inf., vol. 10, no. 1, p. 139, 2021.

[2] I. Pratiwi, H. MZ, and S. Aprilyanti, "PEMILIHAN SUPPLIER TERBAIK PENYEDIA BARANG CONSUMABLE MENGGUNAKAN METODE ANALYTICAL HIERARCHY PROCESS ( Studi kasus di Departemen Pengadaan Barang PT . PUSRI ) THE BEST SUPPLIER SELECTION OF CONSUMABLE GOODS SUPPLIER USING ANALYTICAL," J. Manaj. Ind. dan Logistik, vol. 2, no. 2, pp. 147-158, 2018.

[3] Nurmalasari and A. A. Pratama, "Sistem Pendukung Keputusan Pemilihan Supplier Menggunakan Metode AHP Pada PT Transcoal Pacific Jakarta," J. Tek. Komput., vol. IV, no. 2, pp. 48-55, 2018.

[4] A. Y. Pradipta and A. Diana, "Sistem Penunjang Keputusan Pemilihan Supplier pada 
Apotek dengan Metode AHP dan SAW (Studi Kasus Apotek XYZ)," Sisfotek, vol. 3584, pp. 107-114, 2017.

[5] R. Ginting and Alfredo, "Penentuan Supplier dengan Sistem Pendukung Keputusan Menggunakan Metode Simple Multi Attribute Rating Technique (SMART)," Talent. Conf. Ser. Energy Eng., vol. 3, no. 2, pp. 116-123, 2020.

[6] F. Ayu and N. Permatasari, "Perancangan Sistem Informasi Pengolahan Data Praktek Kerja Lapangan (PKL) Pada Devisi Humas PT. Pegadaian," J. Intra-Tech, vol. 2, no. 2, pp. 12 26, 2018.

[7] N. D. Putri, I. S. Damanik, and E. Irawan, "Analisis Metode SMART Rekrutmen Guru Baru TK/Paud Lestari Di Kabupaten Simalungun," Jurasik (Jurnal Ris. Sist. Inf. dan Tek. Inform., vol. 6, no. 1, p. 207, 2021.

[8] S. I. Pebakirang, A. Sutrisno, and J. S. Neyland, "Penerapan Metode AHP ( Analytical Hierarchy Process ) untuk Pemilihan Supplier Suku Cadang di PLTD BITUNG," J. Online Poros Tek. Mesin, vol. 6, no. 1, pp. 32-44, 2017.

\section{Biodata Penulis}

Maya Nur Amalia, lahir di Jambi pada tanggal 22 Februari 2000. Penulis pertama merupakan mahasiswa aktif di ARS University pada bidang Sistem informasi.

Maxsi Ary, S.Si., S.Kom., M.Kom, lahir di Kabupaten Garut pada 23 Juli 1983, menyelesaikan pendidikan formal S1 jurusan matematika Unisba (2005), S1 jurusan sistem informasi STMIK Jabar (2010), S2 jurusan ilmu komputer STMIK Nusa Mandiri (2011). Saat ini masih proses studi kembali program S3 tahun 2019 program penelitian di Asia e University. Berprofesi sebagai dosen pada program studi Sistem Informasi Fakultas Teknologi Informasi ARS University 